\title{
Hierarchy of Objectives in Health Professional CURRICULUM: FroM TRADITIONAL TO COMPETENCY BASED EDUCATION MODEL
}

\author{
Pradeep Kumar Sahu ${ }^{1}$, Jonas I. Addae ${ }^{2}$ and Bidyadhar Sa ${ }^{1}$ \\ ${ }^{1}$ Centre for Medical Sciences Education (CMSE); ${ }^{2}$ Department of Pre-Clinical Sciences, Faculty of \\ Medical Sciences, The University of the West Indies, St. Augustine, Trinidad \& Tobago, West Indies \\ ${ }^{*}$ E-mail: Pradeep.Sahu@sta.uwi.edu \\ Tel.: +18686828174 .
}

Received: May 11, 2017 / Revised: Jun 27, 2017 / Accepted: Jun 28, 2017

The objectives in health professional curriculum have been expressed in different terms to communicate expectations of the programme. Curriculum designers sometimes encounter difficulties in selecting suitable terms from many identical terms when developing the curriculum. This review helps to clarify the use of different forms of objectives in a traditional or competency-based curriculum in health professional education. In a traditional curriculum, the terms general and specific objectives are used to indicate the purpose of the programme or course; whereas in competency-based education, the terms competencies, outcomes and milestones are often used. Some authors tend to think of objective as an alternative name for outcome and use the words interchangeably. However, the emphasis in the traditional model is on the teaching and learning process whereas the competency-based education model focuses on the outcomes i.e. what the learners achieve at the end of the programme. This review suggests that, whilst developing the curriculum, educators in health professions need to have a clear understanding of the distinction between the objectives of a traditional curriculum and the outcomes of a competency-based curriculum to satisfy the requirements of different stakeholders including accrediting bodies.

Key words: Objectives, Competencies, Competency-based education, Curriculum.

\section{INTRODUCTION}

The key elements that hold together teaching, learning and assessment in a curriculum process are well-stated objectives. In other words, the entire process of curriculum development, delivery and assessment is guided by learning objectives or goals. Clear expectations of what is required from students are critical for effective learning (Ramsden, 2003). Students are much more likely to succeed if they understand the learning objectives when undertaking a programme. Clearly defined objectives help teachers to select proper instructional strategies and identify valid assessment tools to evaluate the performance of students. Well written objectives are useful for all methods of teaching and learning including non-traditional methods such as the "Class Room Seminar and Journal Club" model (Dahiya and Dahiya, 2015).

Objectives effectively communicate to a range of primary and secondary stakeholders about what the students will achieve at the end of the programme. However, writing objectives has always been a difficult task for teachers and curriculum planners. It is stated in the literature that "Writing educational objectives is an underappreciated skill. Despite the importance of objectives, learners, teachers and curriculum planners frequently have difficulty in the formulating and the explaining the objectives of 
the curriculum" (Kern et al 2009).

The word 'objective' has been expressed by using different terms in the process of designing the curriculum to communicate expectations for educational programs. Some of the most commonly used terms of objectives in higher education, specifically in health professions are: programme objective, educational objective, general objective, competency, programme outcome, course learning outcome, course aim, course objective, instructional objective, and learning objective. Curriculum designers may encounter difficulties in selecting suitable terms from seemingly identical terms whilst developing the curriculum. In this regard, it is indicated that "in some cases, the terms are functionally synonymous whereas in others, they are different in both function and structure" (Marken and Morrison, 2013).

\section{Objectives in a traditional curriculum}

The traditional objective-based model was widely adopted in the early 20th century (Frank et al 2010). The literature has several reports emphasizing on the importance of setting up programme goals and objectives for curriculum development (Tyler, 1949; Mager, 1962). This model has still been part of many programmes in higher education including health professions. It is stated that "Broad educational goals (broad educational objectives) communicate the overall purposes of a curriculum and serve as criteria against which the selection of various curricular components can be judged. The development and prioritization of specific measurable objectives permit further refinement of the curricular content and guide the selection of appropriate educational and evaluation methods" (Kern et al 2009).

\section{Programme level objectives - Traditional model}

The objectives set at the programme level are known as Programme Objectives or General Objectives of the Programme or Educational Objectives of the Programme; terms that are often used interchangeably. Programme objectives are content-free broad statements and not course specific. These objectives identify the expected learnings but do not specify particular learning conditions or assessment strategies (Oermann and Gaberson, 2014) and are developed in such a way that they can be applied to different courses; for example: "upon the completion of the medical education the students will have demonstrated knowledge of the normal structure and function of the body (as an intact organism) and of each of its major organ systems" (AAMC Report I, 1998). Further specification of the above example of programme objective is made whilst developing the course level objectives.

\section{Course objectives - Traditional model}

Course objectives are used interchangeably with the terms specific objectives, specific learning objectives or course level objectives. They are specific, observable and measurable in nature and thus help in determining clear learning and assessment strategies. Course objectives focus on what the students should know and be able to do at the end of the course (Weimer, 1996). Whilst framing objectives of the course, the faculty should know how each of them is connected to the programme objectives.

It is essential to set a balanced number of objectives for each course in line with the overall programme objectives. A reasonable number of objectives helps students to focus on what is expected from them in a course. There is some confusion about what constitutes a reasonable number of objectives, although it is suggested 8 to 12 objectives for a course (Linn and Gronlund, 2000), whereas a greater number of objectives may provide clearer expectations to students, unduly long lists of learning objectives end up discouraging students from paying attention to the objectives (Harden, 2002).

Course objectives are developed using action verbs from the cognitive, affective and psychomotor domains to describe knowledge, skills, attitudes and values that the students need to achieve at the end of the course. Hand books available in the literature are widely used in preparing the measurable objectives (Bloom et al 1956; Krathwohl et al 1956). An example of a course objective would be: "upon completion of the course, the student will be able to explain the process involved in cell division". The checklist for setting programme objectives and course objectives in traditional model is compiled in Table 1.

\section{Competency-based education (CBE) model}

During the last few decades, the focus in health professional education has shifted from the traditional-based curriculum to competencybased education (CBE) curriculum (Frank et al 2010). CBE, also known as outcome-based education (OBE), focuses on what the graduate 
can actually do on completion of the health training. CBE is "an outcome-based approach to the design, implementation, assessment and evaluation of medical education programmes, using an organizing framework of competencies" (Frank et al 2010).

Table 1. Checklist for traditional model

\begin{tabular}{|c|l|}
\hline \multirow{4}{*}{ Programme objectives } & Are the programme objectives broadly stated? \\
\cline { 2 - 3 } & Are the programme objectives content free? \\
\cline { 2 - 3 } & $\begin{array}{l}\text { Do the programme objectives provide a framework for } \\
\text { determining the more specific course level objectives? }\end{array}$ \\
\cline { 2 - 3 } & $\begin{array}{l}\text { Are appropriate action verbs used whilst developing the } \\
\text { programme objectives? }\end{array}$ \\
\hline & Are the course objectives specific and measurable? \\
\cline { 2 - 3 } Course objectives & $\begin{array}{l}\text { Are the course objectives consistent with the programme } \\
\text { objectives? }\end{array}$ \\
\cline { 2 - 2 } & Do the course objectives set the basis for assessment? \\
\cline { 2 - 2 } & $\begin{array}{l}\text { Are the course objectives developed using appropriate action } \\
\text { verbs from the cognitive, conative and affective domains? }\end{array}$ \\
\hline
\end{tabular}

It is stated in the literature that "a significant change has taken place in medical education with the move from an emphasis on process, where what matters are the teaching and learning methods, to a product model where the emphasis switches to the learning outcomes of the education experience" (Harden, 2007). The traditional curriculum focuses mainly on 'what to teach', 'when to teach' and 'how to teach' within a given time frame, whereas the CBE curriculum focuses on the competencies needed at the end of the programme. CBE is a visionary new approach to medical education because it emphasised the type of doctor produced rather than the process of education (Harden et al 1999).

\section{Competencies}

The literature has reports explaining that "Competencies are bundles of the essential knowledge, skills, and attitudes (KSAs) required to achieve an acceptable level of performance in the world of practice" (Hooper et al 2014). Students, upon the completion of the health education programme, must have the abilities, knowledge, skills and attitude to become competent in their specific area. However, determining the areas/domains of competency and writing the competencies are a major challenge in health professional curriculum. Competency descriptions are written at multiple levels of detail which start from broad competency domains and move towards general and specific competencies (Gruppen et al 2012). The Accreditation Council for Graduate Medical Education (ACGME) has referred to these levels as competency domains and constituent components. ACGME has identified six broad domains of competency for the residency programme: patient care, medical knowledge, practice-based learning and improvement, interpersonal and communication skills, professionalism and systems-based practice (Swing, 2007). Each domain has certain competencies to be achieved by the learner. These general competencies articulate the knowledge, skills, and attitudes that a student is expected to demonstrate at the end of the programme to become a competent person in his or her area of specialty. Examples of general competencies for one of the domains (medical knowledge) are:

- Obtain biomedical, clinical, social-behavioural and epidemiological knowledge

-Demonstrate investigatory and the analytic thinking

The competencies are set for different programmes based on the priority of the institution, region and country. To make competencies relevant to education, they are translated into much more specific subcompetencies which are popularly known as specific learning outcomes. Figure 1 summarizes the comparative hierarchy of terms used in the traditional and CBE models.

\section{Specific learning outcomes}

Programme level competencies or outcomes are too broad in nature and cannot be assessed as a whole. Thus further specifications of competencies/outcomes are described at the course level. Each competency is supported by 
multiple learning outcomes which are measurable and observable. A learning outcome is a statement of "what the learner is expected to know, understand and/or be able to do at the end of a period of learning" (O'Neill et al 2005).

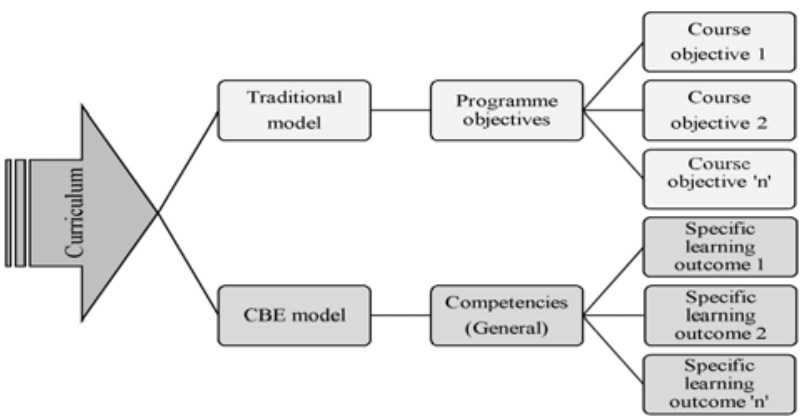

Fig. 1. Objectives for traditional and competency based education models

Learning outcomes can be used to express learning at the level of the unit or module and "In so doing they clarify for the learner what is expected of him or her as well as the skills/competences, understanding and abilities that they will acquire on successful completion of their study" (Froment et al 2006a).

Learning outcomes at course level help in determining the learning methods and assessment strategies. Proper alignment of learning outcomes, learning experiences and assessment mutually reinforce each other (Biggs and Tang, 2011). It is also essential that the learning outcomes and learning activities are aligned with the competencies set for the programme. In developing the measurable learning outcomes, Bloom's lists of action verbs (or the extended and revised action verbs by various authors) may be used to measure the knowledge, skills and attitudes of the students (Froment et al 2006b). The terms used in course objectives (in the traditional model) and learning outcomes (in CBE model) are often similar (Harmon et al 2016). This arises because the process of writing objectives or outcomes both use extensively the taxonomy of educational objectives (Bloom et al 1956; Krathwohl et al 1956). Examples of specific learning outcomes in the basic health sciences and clinical curricula are:

- Describe the functional organization of the nervous system (Knowledge)

- Use effective and empathic verbal and nonverbal communication skills in all clinical encounters with the patient, their families and carers (Skill)

- Respect patient confidentiality, privacy and autonomy (Attitude)

The checklist for setting general competencies/ specific learning outcomes in CBE model is listed in the Table 2.

Table 2. Checklist for CBE model

\begin{tabular}{|c|c|}
\hline \multirow{3}{*}{ General competencies } & Are the competencies clear and unambiguous? \\
\hline & $\begin{array}{l}\text { Are they set in the medical curriculum to produce a } \\
\text { competent physician? }\end{array}$ \\
\hline & $\begin{array}{l}\text { Do the competencies assist in identifying the specific learning } \\
\text { outcomes? }\end{array}$ \\
\hline \multirow{5}{*}{ Specific learning outcomes } & Are the learning outcomes specific, clear and unambiguous? \\
\hline & $\begin{array}{l}\text { Are the learning outcomes demonstrable, measurable } \\
\text { and achievable? }\end{array}$ \\
\hline & $\begin{array}{l}\text { Do the learning outcomes set the basis for learning methods } \\
\text { and assessment? }\end{array}$ \\
\hline & $\begin{array}{l}\text { Do the outcomes describe the competencies set for the } \\
\text { programme? }\end{array}$ \\
\hline & $\begin{array}{l}\text { Are the learning outcomes specifying an action that is done by } \\
\text { students rather than a teacher? }\end{array}$ \\
\hline
\end{tabular}

\section{CONCLUSION}

Traditional curriculum focuses on the instructional process and not the end-results of the programme. CBE is outcome-based and emphasizes what the graduate is able to do at end of the programme without detailing the process to achieve that endpoint. Recently, the regulatory bodies are also directing medical and other health professional schools toward CBE model. Therefore, it is imperative for the health professional schools to have the clearer under- standing of distinction between the objectives of a traditional curriculum and the outcomes of a CBE curriculum in order to ensure compliance with the expectations of the accrediting bodies. 


\section{References}

Adam S. An Introduction to Learning Outcomes. In: Froment E, Kohler J, Purser L, Wilson L (eds) EUA Bologna handbook. European University Association (EUA): Berlin, 2006a.

Association of American Medical Colleges (AAMC). Report I: Learning objectives for medical student education Guidelines for medical schools. Medical school objectives project, Washington DC, 1998.

Biggs J, Tang C. Teaching for Quality Learning at University. $4^{\text {th }}$ edition, McGraw-Hill and Open University Press: Maidenhead, UK, 2011.

Bloom BS, Englehart MD, Furst EJ, Hill WH, Krathwohl DR. Taxonomy of Educational Objectives: The Classification of Educational Goals. Handbook I: Cognitive Domain. Longman: New York, 1956.

Dahiya S, Dahiya R. Class room seminar and journal club as an effective teaching learning tool: Perception to post graduation pharmacy students. J. Effect. Teach. 2015; 15(1):55-70.

Donnelly R, Fitzmaurice M. Designing Modules for Learning. In: O’Neill GS, Moore S, McMullin B, (eds) Emerging Issues in the Practice of University Learning and Teaching. All Ireland Society for Higher Education (AISHE): Dublin, 2005.

Frank JR, Snell LS, Cate OT, Holmboe ES, Carraccio C, Swing SR, Harris P, Glasgow NJ, Campbell C, Dath D, Harden RM, Iobst W, Long DM, Mungroo R, Richardson DL, Sherbino J, Silver I, Taber S, Talbot M, Harris KA. Competency-based medical education: theory to practice. Med. Teach. 2010;32(8):638-45. [DOI: 10.3109/0142159 X.2010.501190]

Gruppen LD, Mangrulkar RS, Kolars JC. The promise of competency-based education in the health professions for improving global health. Hum. Resour. Health 2012; 10: 43. [DOI: 10.1186/1478-4491-10-43]

Harden RM. Learning outcomes and instructional objectives: Is there a difference? Med. Teach. 2002;24(2):151-5. [DOI: 10.1080/0142159022020687]

Harden RM. Outcome-based education: The future is today. Med Teach. 2007;29(7):625-9.

Harden RM, Crosby JR, Davis MH, Friedman M. AMEE Guide No. 14: Outcome-based education: Part 5-From competency to meta-competency: A model for the specification of learning outcomes. Med Teach. 1999; 21(6):546-52. [DOI: 10.1080/01421599978951]

Harmon KC, Clark JA, Dyck JM, Moran V. Nurse Educator's Guide to Best Teaching Practice: A Case-Based Approach. Springer International Publishing: Switzerland , 2016.

Hooper L, Begg MD, Sullivan LM. Integrating competencies and learning outcomes in core courses for the MPH. Public Health Rep. 2014; 129 (4): 376-81. [DOI: 10.1177/00333 5491412900414]

Kennedy D, Hyland A, Ryan N. Writing and Using Learning Outcomes: A Practical Guide. In: Froment E, Kohler J, Purser L, Wilson L (eds) EUA Bologna handbook. European University Association (EUA): Berlin, 2006b.

Krathwohl DR, Bloom BS, Masia BB. Taxonomy of Educational Objectives: The Classification of Educational Goals. Handbook II: Affective Domain. David McKay Company, Inc.: New York, 1956.

Linn RL, Gronlund NE. Measurement and Assessment in Teaching. 8th edition, Merrill/Prentice Hall: Upper Saddle River, NJ, 2000.

Mager RF. Preparing Instructional Objectives. Fearon: Palo Alto, CA, 1962.

Marken J, Morrison G. Objectives over time: A look at four decades of objectives in the educational research literature. Contemp. Edu. Technol. 2013;4(1):1-14.

Oermann MH, Gaberson KB. Evaluation and Testing in Nursing Education. Fourth edition, Springer Publishing Company: New York, 2014; pp. 11-24.

Ramsden P. Learning to Teach in Higher Education. RoutledgeFalmer: London, 2003; pp. 121-35.

Swing SR. The ACGME outcome project: Retrospective and prospective. Med. Teach. 2007;29(7):648-54. [DOI: 10.10 80/01421590701392903]

Thomas PA. Goals and Objectives. In: Kern DE, Thomas PA, Hughes MT (eds) Curriculum Development for Medical Education: A Six-step Approach. 2nd edition, The Johns Hopkins University Press: Baltimore, 2009; pp. 43-56.

Tyler RW. Basic Principles of Curriculum and Instruction. Chicago University Press: Chicago, 1949; pp. 51-9.

Weimer M. Improving Your Classroom Teaching. Sage: Newbury Park, CA, 1996. 